\title{
Middle-income families in the economic downturn: challenges and management strategies over time
}

\author{
Roberta R Iversen \\ riversen@sp2.upenn.edu \\ Laura Napolitano \\ Frank F Furstenberg \\ University of Pennsylvania
}

(Received March 2011 Revised June 2011)

\section{Abstract}

The "Great Recession" that began in 2007 has hurt many families across the United States, yet most research has examined its impact on those already considered poor or working poor. However, this recession has affected middle-income families, whose experiences with economic challenge have seldom been looked at in any detail. Such families have recently been called "the new poor," "the missing middle," and "families in the middle." One in seven American children under age 18 (10.5 million) has an unemployed parent as a result of this recession, and because economic mobility for children in the U.S. is affected by their parents' earning capacities, these children's educational and employment futures may be permanently constrained. The research presented here, which is informed by Weberian stratification theory and capital theories, is based on a small longitudinal subset of a larger, two-country, multicity, mixed-methods study. Two waves of in-person interviews between spring 2008 and late fall 2009, revealed how families experienced the economic downturn, and the management strategies that parents used to try to counter its negative effects. Parents were moderately able to provide financially for their children's daily needs and support children's current school activities, despite income and job challenges and losses, but less able to continue to develop children's future-enhancing capital.

Keywords: recession; economic downturn; families; middle-income; children's education; management strategies; longitudinal; mixed methods; human, social and cultural capital

\section{Introduction}

The "Great Recession" that began in 2007 has hurt many families across the United States whose experiences with economic hardship have seldom been examined (Voydanoff 1990; Williams and Boushey 2010). Most research has examined the recession's impact on those already considered poor or near poor (Acs and Nichols 2010; U.S. Department of Labor 2010). Yet increasing numbers of middleincome families now contend with altered financial landscapes, so much so they have been recently defined as "the new poor" (Smeeding in Goodman
2010), "the missing middle" (Skocpol 2001; Williams and Boushey 2010), and "families in the middle" (Furstenberg and Gauthier 2007). By the end of 2009, an estimated one in seven American children under age 18 (10.5 million) lived in a family with an unemployed parent, nearly double the pre-recession number (Lovell and Isaacs 2010). Although the Great Recession is technically over, the U.S. Federal Reserve Chairman, Ben Bernanke, recently declared that "unemployment is likely to remain elevated for up to five more years" (Chan 2011). Other countries around 
the globe report similar recession challenges (International Labour Organization 2011).

Our concern here stems from findings that the long-term effects of economic downturn among middle-skilled, middle-educated parents in particular, can negatively impact the educational and work outcomes of the next generation (Haveman, Heinrich and Smeeding 2011; Irons 2009; von Wachter 2011). Some have found that early economic disadvantage, including living in households with unemployed parents, effectively relegates children to lower economic productivity throughout their later life (Holzer 2010; Oreopoulous, Page and Stevens 2008; Stein 2010), although others urge caution about such conclusions (Mayer 2010). Similarly, "economic scarring" from recession-induced job loss and falling incomes may "force families to delay or forgo a college education for their children" (Irons 2009), which is concerning in the context of the current labor market pattern of rising educational requirements (Brand and Xie 2010; Danziger and Ratner 2010). Thus, the negative effects of economic downturn are not experienced solely by already-poor families; nor are the effects as short term as is often portrayed (Irons 2009). Indeed, Bernanke has attributed the slow pace of economic recovery to "the worst financial crisis....since the Great Depression" (Irwin, 2011). Accordingly, the ways in which such recessions may disadvantage middleincome families over time are what we begin to examine here.

Conceptually, this research follows classical theories on social stratification, that social class position is strongly influenced by unequal situations early in life that accumulate over time and affect children's odds of success (see, for example, Grusky 1994; and particularly Weber 1922/1978). Such situations are increasingly viewed from a life-course perspective whereby parents strategize and manage their living situations, including their income sources and allocations, toward family well-being in general and child well-being in particular (Furstenberg et al 1999), albeit with varying rates of success. In this paper, we analyze family management strategies and practices in terms of parents' inclinations and abilities to provide the basics and to develop children's human, social, and cultural capital (Coleman 1990; Lin 2001; Bourdieu 2001, respectively; also, Furstenberg
2005; Parcel, Durfur, and Zito 2010) in the context of economic downturn. Development of all forms of capital pertains to processes that occur over time, which makes even the short-term longitudinal analysis presented here potentially informative.

We first briefly examine selected past research on how families' financial situations affect their children, and then describe our research procedures before turning to the findings. The responses by parents to protect their children's opportunities, lead us to speculate in the final part of the paper about the longer-term effects of economic downturn on the economic and educational mobility of children in middle-income families.

\section{Intergenerational effects of family income on children}

A considerable body of research has been devoted to examining the intergenerational effects of families' economic situations on children's educational and employment futures, beginning with Glen Elder's (1999) seminal finding that fathers' job loss during the Great Depression negatively affected the mobility of their sons. However, subsequent work focused more on whether the effects of parents' income-related actions and behaviors on children are direct or indirect, that is, on intragenerational family processes. For example, one strand of research, based on what is often called the family stress perspective (McLoyd 1998; Mistry et al 2002; Strohschein 2005; Yeung, Linver, and Brooks-Gunn 2002), finds associations between families' economic situations, parenting behaviors, and child outcomes, such as school achievement or behavior. Most of these scholars suggest that the effects are indirect and are mediated through parents' mental health. That is, if the economic situation causes the parent great emotional distress, the distress tends to be passed on to the children, usually in the form of harsh or inconsistent parenting practices. These practices in turn negatively affect children's health or school performance and behavior. However, most family stress research has been conducted among families that live in inner cities rather than in the suburbs, which is our site and where economic distress has recently increased (Kneebone and Garr 2010).

From a somewhat different direction, Voydanoff (1990) suggests that a structural perspective on inter- 
and intragenerational responses to economic challenge is also necessary (see also Haley-Lock and Shah 2007; Iversen and Armstrong 2006). Voydanoff identifies the role of the labor market as mediator between family distress and children's psychological and achievement outcomes. She highlights what she calls economic deprivation, which she defines as "the inability to meet current financial needs and the loss of financial resources and income over a period of time" (p. 1103), and as "the loss of income because of employment instability" (p. 1104), both of which are rife during a recession such as the latest one. Although her focus is on how the labor market affects family relations rather than on children's outcomes per se, her emphasis on the role of employment is relevant to our inquiry.

Finally, Furstenberg and colleagues (1999) integrate process (parenting practices) and structure (aspects of economic opportunity) when they examine education pathways of successful adolescents aged 11 to 14 in a mixed-income sample of Philadelphia families. In that research, parenting practices composed only a portion of the ingredients that produced successful development in early adolescence. More generally, Furstenberg and colleagues' focus on family management refers to how parents manage their family lives and the external world: in particular, whether and how parents engage in multiple and concurrent strategies on behalf of their children's current and future development. Of relevance to our study are the strategies that parents use to manage family life and children's futures and whether such strategies are able, in the context of economic downturn, to develop the human, social, and cultural capital that adolescents need for the futures the parents have in mind for them.

Moreover, with a few exceptions (Conger, Conger and Elder 1997; Furstenberg et al 1999; Land 2010), research on family income and child outcomes has focused on the experiences of children of preschool and elementary school age, rather than on adolescents, as ours does, and on children in povertylevel or near-poor families, rather than on those in families with middle incomes. Further, in contrast to most prior research, our study is longitudinal rather than cross-sectional in design. Uniquely, these data were collected at the beginning of the recession, when its full effects were not yet fully visible, and between twelve and eighteen months later when the recession was in full bloom. Accordingly, our aim is to explore the links between family income in the midst of a recession, and parental responses or management strategies that are commonly related to survival in the present as well as to longer-term social and economic mobility. We acknowledge that an eighteen-month time span is short for study of longitudinal processes, but we hope that the interview detail in the findings will augment earlier inquiries and foster future ones.

\section{Research Procedures}

When the Great Recession officially began in December 2007, we had already launched a comparative study of middle-income families in the United States and Canada. The study was designed to examine how national policies might buffer some of the hardship in families with moderate earnings ${ }^{i}$ (Furstenberg and Gauthier 2007). The families in this report comprise a longitudinal subset, embedded in that larger cross-sectional, two-country, multi-site, mixed-methods study, with the attendant benefits of multiple modes of inquiry and of inquiry over time. The families live in a suburban town of nearly 100,000 in the greater Philadelphia area (Pennsylvania, U.S.).

In spring 2008, parents in 238 families who had been recruited through the town's public middle schools (grades 6-8) completed a short survey about how well they were doing economically. All families had at least one child in middle school. In spring and summer 2008, we randomly selected and personally interviewed at least one parent in $\mathbf{3 1}$ families from two middle-income categories (see description below), whom we call the study parent. To assess how the families were doing as the recession deepened, we re-interviewed 25 of the 31 families in summer $2009^{\mathrm{ii}}$ and interviewed five additional families in fall 2009 that we selected randomly from the original 238 survey responses ${ }^{\text {iii. }}$.

For the 2008 interviews, the families were selected according to reported earnings of either $\$ 45,000-\$ 60,000$ or $\$ 60,000-\$ 75,000$, which we designated as middle income. Although there is no consensus in the literature about how to define middle income (FinAid.org 2010), we used the range that other scholars employ, which is family income 
that falls within $75 \%$ to $125 \%$ of the median family income (Birdsall, Graham, and Pettinato 2000; Pressman 2007). According to the 2008 American Community Survey/1-Year Estimates, median income was $\$ 63,366$. Using the $75-125 \%$ metric, the range is $\$ 45,136$ to $\$ 75,226$. With adjustment for family size, the $75-125 \%$ range became $\$ 45,136$ to $\$ 90,000$ (Personal communication with Anne H. Gauthier, University of Calgary, August 19, 2010). Thus, in fall 2009, to more closely match the sample that had been recruited in the other U.S. site (Tacoma, Washington) and the equivalized $75-125 \%$ range, we randomly selected and interviewed five families who had reported incomes of $\$ 75,000$ to $\$ 90,000$ on the 2008 short survey. Overall, a broadened classification of families as "middle income", allowed us to examine sources of family financial security and insecurity in 2008 and how these led to strategies and prognostic possibilities over the eighteen-month time period.

In both years, interviewed parents also completed longer, semi-structured questionnaires. Income group data in this report derive from those questionnaires, but quantitative findings are reported elsewhere (e.g. Gauthier, Budd, Furstenberg and Pacholok 2010). The findings in this paper, consistent with our attention to family management strategies and practices in the context of shifting economic conditions, derive from qualitative interviews that reflect the experiences of 30 families $^{\mathrm{iv}}$. These interviews lasted from one to three hours and were conducted by the first author of this report (2009 only), the second author (2008 and 2009), and an additional researcher in 2008 only. The families received modest honoraria for interview participation, and study procedures were approved by the University of Pennsylvania Institutional Review Board. We digitally recorded, transcribed, and analyzed the interviews with the help of Atlas.ti, a qualitative analysis program, to ascertain similarities and differences across families' experiences and views. Given the small scale of this analysis and the short longitudinal time span, the results are merely suggestive.

\section{Family Management Strategies and Practices}

Typically, parents in the U.S. as elsewhere focus on providing for their families in two main areas: 1) financially, providing living space, food and clothing for the family's immediate needs, at a minimum; and 2) providing for their children's current and future education. Parents try to satisfy these provider goals through decisions and actions that we call family management strategies and practices. Such practices are aligned theoretically and often concurrently with concepts of financial, human, social and cultural capital. We present the results here in the form of parents' stories, that illustrate what happens with their provider goals in the context of economic downturn.

\section{Providing financially for the family}

Families' income and finances over the study period changed in multiple and often overlapping domains, such as employment status, employment conditions, and savings, emergency funds and debt, all of which impacted the amount of income available to parents toward their goals and practices. To compensate for financial losses, parent strategies included refinancing a home, thus using debt as a safety net, altering spending patterns, seeking a second job, and remarriage, as will be seen through the parents' stories. We focus on the plusses and minuses of two common compensatory strategies, refinancing and spending adjustments, at the end of this section.

\section{Employment Status: John and Alex's Story"}

In 2008, all the parents who wanted paying jobs were employed. John and Alex, parents of two adopted children with special needs, were employed full time, but both parents lost their jobs in January 2009. John and Alex were architecture and real estate professionals respectively, in a 26-year gay relationship when they adopted their then (2009) 13year-old son and 9-year old daughter in 2005. In spite of state adoption support of $\$ 12,000$ annually, John reported a 2008 income of $\$ 45,000$ to $\$ 60,000$ in 2008 , but his response may have been based solely on his income since the family was not eligible to file jointly. Alternatively, Alex's income may have been declining throughout 2008 as during the summer interview he had expressed concern that the real estate market would begin to falter, as was already the case nationally (MPIP 2010):

"The economy is in such a state of turmoil right now. My office, because we're a real estate 
office, we're running things very close to the vest right now as far as money coming in. Right now [summer 2008] things are fine, but we don't know what it's going to be like in November and December when nobody's buying houses. Am I going to have a job in three month"?

John, on the other hand, was confident that his architecture position was secure because the firm specialized in medical facilities, which he expected would always be needed.

Having waited for a long time to be parents, John and Alex were deeply dedicated to their children's physical and educational wellbeing. Despite the children's special learning and developmental needs, John and Alex's educational goals for them, that both children would finish high school and that their daughter might attend some college, remained constant over 2008-09. To these ends, in 2008 they used their adoption support money for the children's daily needs, and augmented basic sustenance actions with capital-building activities such as season theatre tickets and summer camp. By summer 2009, however, John and Alex reported family income in the same range as 2008, but now from Unemployment Insurance (UI). Their greatest single financial burden was health insurance. In 2008, before John and Alex were laid off, John's firm had provided health insurance coverage for domestic partners. This was very fortunate in that both men endured some serious illnesses during the period. Once John became unemployed, he was unable to cover Alex with his COBRA policy ${ }^{\text {vi }}$, which meant that both men had to buy individual policies. As such, their health insurance costs more than tripled, going from $\$ 350$ a month (coverage for both) to $\$ 800$ a month for Alex and $\$ 400$ a month for John: $\$ 1,200$ a month total. As a result, Alex had not taken a required daily medicine for a couple of months.

In light of these financial strains, one of John and Alex's survival strategies in 2009 was to curtail the children's activities. As John said ruefully, "We did have them in the local YMCA summer program [last year], which we just can't afford to do this year." Fortunately, their daughter was just under twelve, which seemed to be the cutoff for state help for special needs children's summer activities; unfortunately, their son was 13 and no longer eligible for state-aided summer enrichment. Other financial strategies included turning "vegan out of necessity" to avoid spending money on meat, giving up theatre tickets, using private food banks, using credit cards sparingly, and buying in bulk. In effect, these strategies constrained the parents' ability to provide extra human and cultural capital for the children.

John and Alex's primary financial survival strategy, however, had been to religiously save money in their "rainy day fund" - a strategy that they had followed for virtually their entire life together and which had allowed them to weather earlier recessions. In 2008 they expressed complete faith that their fund would be sufficient for the future. In 2009, they were worried about the long-term financial effects of the recession, in part because their ages of 55 and 49 placed them in a demographic group that finds it increasingly hard to find new or financially satisfactory jobs, consistent with national patterns (Haveman, Heinrich and Smeeding 2011). While they energetically and optimistically sought new niches for their talents, including using the federal one-stop career centers, their anxiety and concern about their ability to adequately support their children was palpable in the 2009 interview. As John said, "We've been through this recession thing before, only this one's bad, not like the others, which were bad but not as bad as this one."

John's and Alex's UI money was scheduled to run out in January 2010. They expected that their substantial rainy day fund would be depleted about six months after that. Nationally, when UI benefits are exhausted, families' consumption falls, reemployment rates decrease, and the incidence of poverty rises (von Wachter 2011, p.1). The fact that in 2008 these parents' savings were one of the highest among the study parents, reminds us that sole reliance on savings is limited as a long-term strategy, especially when parents are in a hard-to-employ demographic, and particularly when policies, such as filing taxes jointly and accessing affordable health insurance coverage, exclude certain family forms.

\section{Employment Conditions: Susan's Story}

More commonly, employers reduced workers' hours or days at work (Lambert and Henly 2009), which lowered family incomes, or required employees who remained after layoffs to work more hours, which sometimes led to more income but also increased 
parents' time stress, and generally did not compensate for the concurrent increases in everyday costs. As one parent bemoaned, "Everything's going up except my paycheck." Equally problematic for these families, many employers reduced or eliminated the possibility of working overtime. Overtime income had previously provided vacations for some families, religious-school tuition for others, and general subsistence for most, as Susan's story illustrates.

Susan is a 49-year old married mother of two children, aged 14 and 13 in 2008, who worked full time as a school secretary for $\$ 18,000$ a year (in 2008) because of the school district's "great benefits." Her son had earlier been diagnosed as autistic, but was mostly mainstreamed by 2008, and her daughter's earlier ear surgery had resulted in some permanent hearing loss and special learning accommodations. Susan graduated from a community college in 2008 with her associate's degree in education and wanted to pursue her bachelor's degree to upgrade her career and income. Even with such a degree, a job in the school district would not be high paying, as her comments below inform us. Her husband David was a truck driver for a home materials supply company. They earned between $\$ 45,000$ and $\$ 60,000$ a year in both 2008 and 2009, so even in 2008 this family felt the results of rising costs, as Susan reported: "Since January, there's been no extra money...it's being eaten up by the cost of food and gas....it's just the economy; it's strictly the economy." As a result, Susan's daughter was not able to participate in her usual summer enrichment activities or take desired guitar lessons for $\$ 75$, which reduced the human and cultural capital those activities could bring. Susan's daughter had, however, been part of the elementary and middleschool band for the past five years and Susan hoped she would be involved in the high school band in fall 2009, though it would be a class not an extracurricular activity, which may reduce its appeal to her daughter.

In both 2008 and 2009, Susan was adamant that her children would obtain four-year college degrees, even though Susan's own goal of earning a bachelor's degree was put on hold in 2009 because of the recession: "The recession kind of dictated that we're going to have to wait a little bit longer for me to go to that four-year [institution]". Her children's pathways had been stretched out as well, for by 2009 Susan anticipated that if the children did pursue four-year degrees, it would probably take them six years financially-largely a result of how the downturn had affected David's earnings, as she related:

"It's been a rough year... I didn't realize how rough until we sat down with the accountant to do the 2008 taxes, and then it hit us right in the face. We knew that we were having difficulties. My husband had lost most, if not all, of his overtime, and when we sat down with the tax accountant, it was obvious, $\$ 8,000$ less last year...90\% of his overtime. So that was a really heavy hit.... We told our kids they were old enough, they weren't six years old anymore, this is the way it is... We don't go to the doctor's every time you have the sniffles....I actually went back to school to save my job, because of No Child Left Behind, and working in a school I needed to be certified and there was no certification at the time, so I decided to get the Associate so nobody could say this certification is no good. But as a teaching assistant in a local school district, you're making poverty... Even if I got my four-year degree and went into the public education system, I'm still in my local district only thinking about making $\$ 35,000$ a year.... The biggest thing that I kept trying to remember coming into this was we lost $\$ 8,000$ last year. That, to me, is the thing that if it's happening to me, it's happening to a whole lot of other people".

In addition, David was quite concerned about layoffs on his job, as there were rumors about branch closings and, for those who remained employed, no cost of living increases. David's company was particularly hurt by the downturn in the construction industry and related house building and repairs -a major industry sector that is not expected to rebound for years (O'Leary 2010). In fact, because David's employer reduced overtime possibilities so drastically, both parents were looking for second jobs, though unsuccessfully so far, in order to better manage the first aspect of parental provision - mortgage (shelter), clothing, and food.

\section{Savings, Emergency Funds and Debt: Mary's Story}

The ability to amass savings and emergency funds provides another lens on parents' financial challenges and strategies (Tufano and Schneider 2010) as well as on families' potential economic mobility more broadly (Cramer et al 2009). As Susan's experience illustrated, 
most families in our study reported reductions or depletions in at least one area of savings between 2008 and 2009, such as bank savings accounts, Individual Retirement Accounts (IRAs), or emergency back-up funds, and often in more than one. Moreover, where possible, savings strategies had been oriented to both children's education and parents' retirements. In 2008 the children's future needs came first, but by 2009 parents were increasingly fearful that their retirement accounts would be lacking.

In addition to depleted savings over the 2008-09 period, virtually all the parents reported increased levels of debt, primarily from credit cards, which had become a largely unmanageable economic challenge for low- and middle-income households across the U.S. during the downturn (Garcia and Draut 2009; Pressman and Scott 2010), including many families in this study. Strategies such as adding a second income, either by a second job, which Susan's story revealed as quite difficult to attain, or marriage/partnering, helped some to decrease or avoid adding to their debt. However, marriage wasn't an automatic financial boon, as Mary's story illustrates. Her story details both the tenuousness of middle-income families' savings accounts and the tension parents experience between saving for their children's futures and their own.

In 2008, Mary was a single mother of two children, a 13-year-old daughter and a $21 / 2$-year-old son. Mary's mother, in her early 70s, lived with her, which helped considerably with Mary's daily hour-long work commute each way but was also a strain because the mother had some chronic health problems. Mary told us she had earned about $\$ 40,000$ in 2008. Building on a couple of years of college after high school, Mary was currently taking one online course a semester toward her Associates degree in business administration, which her job paid for.

Mary was very focused on providing educational and neighborhood stability for her daughter and acknowledged the importance of extra-curricular activities for skill-building and enrichment (i.e. human and cultural capital) and, implicitly, as bridging social capital. She is the only parent in the study who verbalized the importance of "connections" for her children's futures: "I want her to know the same people [referring to good friends throughout her school grades] because I did not. It's a lot harder to get through your life when you don't have those resources." At this point, Mary's educational goals for her children were to "graduate college," either twoyear or four-year.

Mary's situation was notable for the rather large educational fund she had already set up for her children's education, "a small secondary IRA of about $\$ 11,000$," but even in 2008, Mary's contribution pattern was changing for financial reasons: "I have backed off on how much money I'm putting in there, because with the economy, gas, and energy crisis.... need the cash to live on, so I think there's $\$ 50$ a month going into that IRA." Mary's strategy was that her daughter would "think about saving and working too," which recent research finds increases college attendance among children in families such as Mary's, regardless of family income or academic achievement (Elliott and Beverly 2010).

Mary also tried to save for her own retirement, which by 2009, despite the fact that she had remarried in the interim and the family income increased to between $\$ 75,000$ and $\$ 90,000$, had become more difficult. As Mary noted, "financially it has been a little rough since last year." She and her husband had two incomes but also two sets of expenses, and most of the debt and costs were premarriage: "So my husband and I now find ourselves in a position where every last penny that we have is going towards historical things." Strategies that Mary invoked to deal with persistent financial challenges included refinancing her house, which produced a higher rate of interest but some much-needed cash, and stopping her online education, partly as a jobsaving maneuver because she didn't want to cost the company money and risk losing her job "when the economy hit rock bottom." Employees in Mary's firm did not receive a raise or a bonus in 2008/09, which meant a loss of between $\$ 2000$ and $\$ 3000$ dollars and correspondingly less to deposit in her retirement account.

As mentioned briefly in these stories, the families' strategies to contend with the financial impact of the economic downturn took two main forms: reducing debt through refinancing the home and reducing the financial outgo by spending less or differently. Typically these strategies took place concurrently, which we examine now in more detail. 


\section{Refinancing Strategy: Stephanie's Story}

Refinancing a home mortgage with a lower interest rate was a common strategy parents used to manage their general financial challenges. As part of refinancing, families often borrowed an additional sum of money, such as $\$ 5,000$ or $\$ 10,000$, to use for household or other expenses. As such, refinancing can be a constructive short-term, safety-net strategy vii, even though it generally lengthens the term of the mortgage. In the longer run, the volatility in employment and income that is typical during economic downturn (Dynan 2010) can lead to increased debt and a lower family credit rating. A related strategy was taking out a home equity loan whereby a family qualified for the loan by using the equity they hold in their home as collateral. Home equity loans can be either a lump sum or a revolving line of credit, but if they are not repaid on time, the creditor can require that the property be sold. In 2008 none of the families talked about foreclosure, but by 2009, many parents reported foreclosure sales in their neighborhoods, downward valuation of their properties, and fear of foreclosure for themselves.

Foreclosure notwithstanding, at least half the parents had recently used refinancing or home equity strategies to meet their family's expenses and children's needs. For example, Stephanie, a divorced mother of three daughters, ages 18, 16, and 12 in 2008, received no child support and also tended daily to her chronically ill father who lived in a nursing home. Stephanie has been a nurse in an area hospital for 30 years. In 2008, with an annual income between $\$ 45,000$ and $\$ 60,000$, she consolidated her mortgage, real estate taxes, and her credit card debt into a single $\$ 30,000$ home equity loan that she pays monthly. Even in 2009 when her income increased to between $\$ 60,000$ and $\$ 75,000$, current and upcoming college costs for two of her daughters and her monthly loan payment ate up virtually all the increase. Stephanie's goal was to complete the loan payment by the time her youngest daughter goes to college, but she acknowledged that this strategy leaves little room for emergencies in the interim:

"We'll see....I feel like if something happened to me and I got $80 \%$ of my pay or $70 \%$ on disability, I would probably sink, and that's the insecure part 'cause there's nobody out there that can help me".
Given that the home is these families' primary asset and that equity strategies are based on the assumption that house values will continue to rise, which has not been the case during this recession, many families like Stephanie's are thus gambling on their financial and their children's futures for shortterm benefits.

\section{Spending Strategies: Amy's Story}

In 2008 only a few families found it hard to afford what their children needed, but in 2009 many more families - in fact virtually all - found such provision difficult, due mainly to the recession or the recession plus related management or budgeting problems. Given that annual child-rearing expense estimates nationally range from $\$ 8,330$ to $\$ 23,530$ (in 2009 dollars) for middle-income families like those in this study (Lino 2009), and that such expenses are highest for families in the urban Northeast, it is not surprising that almost all the families had curtailed or become even more strategic about spending by 2009 . Families commonly limited or eliminated spending for entertainment, eating out, zoo membership, YMCA membership, clothes, or children's instrumental or dance lessons-notably, activities that bolster human, social and cultural capital. Amy's spending story is one of the most dramatic but also typical of the strain families reported in the recession climate.

In 2008, Amy and Marcus's daughters attended dance classes for "ballet, tap, jazz, modern, African," which they had gone to "all their lives." The parents valued this activity for the daughters' learning, for what it could lead to in their futures, and for the pride they felt in their children's accomplishments. Earning between $\$ 75,000$ and $\$ 90,000$ in both 2008 and 2009 from their full-time jobs plus Marcus's second part time job, the parents were still able in 2009 to engage in their usual summer vacation activity, which involved extended family, and take occasional weekend trips, but "with subtle differences...[because] we're not as comfortable [financially] as we were a year ago." The parents were down to one car from two in 2008 and by fall 2009, Marcus's hours were cut back at his second job. Overall, Amy found that expenses had risen but their incomes had not. As a result, Amy decided to eliminate the girls' dance classes. Amy had earlier reasoned that she expected that both daughters 
would go to college, but because they didn't have any money saved for that, she thought that dancing might facilitate her older daughter's college entrée:

"I just had visions of her going further with it [dancing]. And she said, 'I'm not going to be a dancer, you know, I do it, I'm good at it, but that's not what I want to do.' So I had to say, 'you know, this isn't what you're gonna do, we need to find what that is, because we don't have money'...To put it blankly, we need scholarships".

Countering Amy's reasoning, however, the tenthgrade daughter will not be able to show college admissions analysts her consistency and persistence in a demanding activity such as dance. Potentially worse for admission chances, neither daughter had substituted school- or community-based extracurricular activities for the dance classes. And in a challenge parallel to what other parents experienced, Amy wished she could return to complete her four-year college education, having returned for additional credits toward her bachelor's degree about five years earlier, but rued that furthering her education now wasn't financially feasible as her daughters were nearing college age:

"It's like, it's something that I want to have, but is it practical when I have these girls like because their future is brighter than, you know, than mine at this point. It's, you know, it's just a, it's a trade-off and I have to work out within myself. I, I haven't come to a remedy for that yet".

Parents' spending strategies also included economizing and cutting back on consumption, including food, goods, and gas. They distinguished anew between "wants" and "needs," asked their children to contribute to their own purchases and develop their own savings accounts, and tried to learn or improve budgeting and money management practices. What little vacation was planned, typically involved family, such as staying at a grandparent's trailer at the shore, rather than the cultural capitalenhancing vacations of the past, such as a cruise won by one parent and out-of-state travel.

In a few instances, prior spending problems improved in 2009 over 2008. An inheritance eased previously frugal spending patterns for one family and also fostered their consumer spending and savings.
Job promotions eased a few families' spending patterns, but were double-edged because promotion to management generally meant ineligibility for overtime. In addition, many parents' concern about their own financial futures meant that any extra money went into retirement accounts versus into children's college accounts. As one parent put it, "She can get a loan for her education. I can't get a loan for my retirement."

Overall, the parents' financial strategies can be considered only moderately effective. The strategies buttressed parents' ability to provide adequately for children's current needs, even as family incomes and employment conditions worsened, but they reduced parents' ability to build additional human, social and cultural capital for their children's futures.

\section{Providing for children's education: strategies and practices \\ Providing for current and future education}

Providing for children's education was a priority in all the families. Parents focused most strongly on their children's current education, even though their emphasis on extracurricular activities inadvertently might foster future possibilities. Strategic thinking about how to fund children's future education, however, remained generally underdeveloped. In the following stories, as in the earlier ones, aims and strategies are interwoven, but Maria's story at the end of the section describes one of the few positive funding situations.

\section{Children's current education}

In 2008, most of the families told stories about choosing their home and neighborhood at least partly, if not solely, on the basis of the reputation of the local schools. Some had even moved to the suburb from Philadelphia to enhance their children's school experience. In 2009, parents remained satisfied for the most part with their choice of neighborhood and, particularly, its local elementary school. Most also found the neighborhood middle school to be hospitable and adequate in quality. Many expressed concern about the size of the single high school, yet at the same time heralded its many opportunities as long as children didn't get "lost." Parents volunteered actively in the elementary schools if they were at-home mothers, or if their 
work schedule allowed, and many mothers chose to work in the school district, even though the pay was extremely low (see Susan's story, earlier), in order to have the same schedules as their children. Few parents reported children's behavior or performance problems, although this could be an artifact of which parents agreed to participate in the interview portion of the research.

As a whole, parents focused intensively on sustaining children's participation in extracurricular activities. In 2008 most said that their children were involved in school-based and/or community-based extracurricular activities-predominantly sports but clubs, music, and drama activities as well. Most school activities were free or had only a small equipment fee, whereas costs for outside-of-school activities ranged from $\$ 150$ a season to $\$ 8,500$ a year for the two children in dance described earlier in Amy's story. Even in 2008, many families reported difficulty affording the cost of their children's activities, especially when two children were in high school or middle school at the same time. By 2009, limiting the number of activities was a relatively common strategy, as Elizabeth described: "There's just not enough money for extracurricular stuff...I want my daughter [age 10] to be in something, but we can't afford it." Elizabeth's 13-year-old son really wanted to learn golf, but attended a game club at the local library instead.

For the most part, even in 2009, parents chose to support at least some of their children's extracurricular activities, often sacrificing their own needs and wants in the process. Most valued these activities because they "keep kids out of trouble." Others felt that such activities taught children skills and provided entertainment and a sense of community for the parents. None of the families associated extracurricular activities with their child's grades, and none explicitly associated such activities with building social networks for their children's futures.

Children's educational futures: Samantha's Story; Lola's and Martina's Observations

Parents' views about and strategies toward their children's educational futures, were far more complicated than their thoughts about fostering current school experiences. At base, all the parents associated post-secondary education with the ability to get a good-paying job, viii as others also find (Danziger and Ratner 2010). Indeed, over the eighteen months, a growing number of parents said that they expected their adolescent child to go to college, and often all of their children. Although in 2008, two-year programs, trade schools and the military were mentioned quite frequently alongside ideas about college, in 2009 the focus was strongly on four-year colleges and bachelor's degrees. Parents attributed their upgraded schooling goals for their children, to experiencing greater fear of layoff because of their own perceived educational insufficiencies.

Samantha's comments were typical of this pattern. In 2008, Samantha's husband Dan was a strong proponent of college for their then 14-, 12-, and 5-year old children, but Samantha's opinions were quite opposite: "I'm not a huge advocate of college. To me it's the money issue. It's so much money to have your kids go to college. I just think it's ridiculous.... if they went to a trade school, that's fine." Neither Samantha nor Dan's parents went to college, though Samantha started at a community college and dropped out before the first semester ended. In 2008, she was an at-home mother with a $\$ 100 /$ week child-sitting job.

By 2009, however, the family picture looked very different. Dan had developed an intestinal disorder that limited how much he could work. Because Dan had previously worked the equivalent of nearly another full-time job doing "side jobs," the family's annual income had increased from between $\$ 60,000$ and $\$ 75,000$ in 2008 to "about $\$ 79,000$ a year" in 2009 before his health problems. Dan's now-chronic health concerns acted as a wake-up call for Samantha, in that she now wanted the children to have direction. She knew if something even more dire happened to her husband, she'd be in deep financial trouble, because she had no career direction or skills, and she did not want her children to ever be in the same predicament:

"When Dan got sick I really, I mean... So initially [2008].... wouldn't care if my kids went to college or not, because I still feel like you could get a good job, but now [2009] I really do want my kids to have some kind of a 
degree....because nobody can take that away from them...I want them to be self-sufficient".

Paradoxically, in contrast to rising educational goals for their children, parents also felt that their hopes were less and less realistic. In 2008, most thought their goals were financially achievable but many fewer held that view in 2009, as Lola's comments suggest:

"Yeah, I think financially it's too hard for me to say...Like we're maintaining. It's not possible at this point to be putting away money for that, so we'll see how things go as the time goes on. I mean I've got four years, four years. It will go quick". (Lola, age 44, divorced, three children, ages 13, 13 and 10 in 2009, works full time. Family income $\$ 45,000$ to $\$ 60,000$ in both 2008 and 2009).

Countering the rising educational goals and perhaps reflecting families' altered financial realities, by 2009 some parents expressed ambivalence about the financial benefits of a four-year college education, and a few lowered their expectations because they'd seen job loss among professionals, while they or their spouse had retained a trade job, as Martina noted:

"I don't know if they'll end up in college or not. I'd like them to. I mean, with my two older kids it was like, you know, there was no talking about it, they had to go, but I've changed my mind that way... When a lot of people were getting laid off from some pretty big corporate jobs, my husband [a self-employed construction contractor] was still working. And a couple of the people who lived around here said they wished they could do what Jim did, because there was still demand for that". (Martina, age 49, six children, ages 30, 28, 16, 14, 12, 10, worked part time at two nursing jobs, but had no post-secondary degree. Family income $\$ 45,000$ to $\$ 60,000$ in 2008; $\$ 90,000$ to $\$ 105,000$ in 2009 due to a doubled number of family earners).

Martina's observations were echoed by national reports about the doubling of unemployment rates among college graduates between December 2007 and December 2009 (Hartmann, English and Hayes 2010). Finally, given the normative emphasis in these families on providing educational opportunities, savings strategies were severely underdeveloped. Only in rare cases, such as Maria's story illustrates, did children's college futures seem relatively financially secure.

\section{Savings strategies toward children's educational futures: Maria's Story}

In 2008, most parents expected to use general savings to pay for children's college costs, but by 2009, many fewer did. Some parents had not even thought about how they would finance their children's future education, although one parent hoped he'd hit the jackpot, another planned to use the children's piggy banks as a savings start, and one mother intended to return to work. The difficulty parents had in maintaining savings accounts described earlier in Mary's story, for example, was particularly relevant to children's accounts, which were often the first to be raided, though in some cases they were sacrosanct.

Even in families that struggled financially in 2009, grandparents' assets and wealth offered strategic help for children's futures. In Maria's family, for example, total earnings remained between $\$ 45,000$ and $\$ 60,000$ during the recession years despite the fact that she worked part time and her husband worked full time. In both 2008 and 2009, the parents struggled with the extra costs for dances, school trips, and other special events for their two children in middle school. Lessening the level of cultural capital available to the children had been one of the parents' financial strategies over the past year, as Maria reported: "Even the kids' activities, what they can do and when they can do it, it always comes that way because money is just not there." In the 2009 interview, Maria further described a roller-coaster of challenges over the past year and the implications of that for their family.

"When we were here last time [2008], I had just started with a new job. Um, and it was an upswing for us because it was more money and it really was helping us out. And all through the summer it was a really good thing. We seemed to be on a little bit of an upswing because of that extra money. Once we got into the holidays and after the holidays in January (2009), it seemed to be...things were starting to hit the down, gas prices were up. Even though I was making more money...It really started to seem like I was back to where I was before I had this job.... and with 
school activities, I mean, I just didn't realize how expensive with two kids in the middle school the activities were. And we leveled off and then we started hitting that little bit of a down, a down thing. My husband got some overtime. We came up a little bit like, probably February/March we went up again, and then his company started making cuts and the overtime stopped. And so now here we are back again, back on the down end of it. I think we've leveled off. I don't think we've really hit really down. I think we're a little above where we were at this point last year [[which is basically the tips of their noses above water]].... I mean, we did a lot of smart things. We paid off our debt, so we're in a really good position where, you know, we don't have credit cards... We have one credit card we use. We pay it off when we use it and we just have our bills, which has really helped us out a lot, so that's good".

Counterbalancing these struggles and rare among the study parents, Maria's father-in-law had established sizeable funds for the children's college needs, which may make the parents' current financial dilemmas less dire for the children's futures.

"My father-in-law has been very generous. He's set up funds for all three of them, um, that are pretty substantial, and probably by the time that Dominic (age 14 in 2009) goes to college...If Penn State doesn't go up significantly, what my father-in-law has put aside for him should pay for about a year and a half, which would be wonderful....And the same thing for Susan (age 13 in 2009). And then for June (age 8 in 2009), who knows what's gonna happen by the time that kid gets to school, you know.

\section{Implications of economic downturn and parent strategies for children's educational futures}

This research on "families in the middle" extends the recent findings of Irons (2009) and Lovell and Isaacs (2010) about recession-induced financial challenges on formerly non-poor children and their families, accounting for both structural (e.g. parents' income and employment) and process (e.g. parents' and children's management strategies) phenomena. All parents experienced resource restrictions in the economic downturn that touched their family members. In response, most families deliberately tried to sustain provision of basic needs and maintain their children's current educational opportunities and activities. Because of these adaptations, we found less evidence than might be expected that the Great Recession was reducing parental investment of time and resources in their children. Still, none of these middle-income families escaped the economic downturn unscathed. In most, future-oriented building of cultural capital, such as through travel, a full array of school-year extracurricular activities, and summer enrichment ventures, was constricted or eliminated by recession-induced financial challenges due mainly to income changes and employment conditions.

As the recession deepened, fewer parents believed that their expectations for their children's post-secondary activity would be realized, which is particularly concerning because of the growing link between education and later-life returns to employment. In addition, most study parents regretted that they had delayed or depleted savings, in general and for older children's post-secondary education, such that financial support for their younger children's educational futures was now uncertain. Still, most parents maintained or increased their valuation of a college education (generally fouryear) for their children, even if they had few concrete ways or plans to finance it. They associated this heightened valuation with their own and others' experiences during the economic crisis, such as fear of layoff, job loss, and inability to seek a higherpaying job because they lacked a college credential. And although some technical and trade credentials are expected to yield moderate incomes in tomorrow's labor market, the highest incomes are still forecast for those with four-year degrees, especially "among individuals (such as many children in our study) with a low propensity for completing college" (Brand and Xie 2010, p. 293).

The full impact of the economic crisis on the study children's future educational attainment can only be surmised at this time, particularly from a small-scale study such as ours and because the recession's effects continue to be widely felt (McNichol, Oliff and Johnson 2011). The worst case is that the recession's constraints on full development of children's human, 
social, and cultural capital will result in decreased economic attainment throughout adulthood. A more optimistic scenario, which could be examined by extended longitudinal inquiry, is that middle-income parents' vigorous attention to their children's futures overall, as evidenced by the study parents' management strategies, can provide at least basic capital for children's educational and economic futures. One caution, however, is that this recession leaves limited room for many parents to improve their own educational futures with new and more rewarding jobs, and for building financial support for their later years. Indeed, Susan and Mary and other parents in our study, acknowledged the painful dilemma between helping their children to succeed in school and protecting their own limited assets. The parents' need to choose between their children's educational futures and their own, may further limit younger children's educational futures by decreasing family mobility.

In times of major change, and particularly financial change, even a relatively short-term longitudinal panel study can reveal a rich range of family responses such that opportunities, costs and life chances are better understood. The next step is to ascertain with more certainty, what the long-term effects of recession-induced reductions or constraints are on children's capital development. At this point, our findings suggest that the American approach to off-loading much of the cost of higher education onto families who are economically stressed, which occurs in middle-income families more often than is generally recognized, is not viable if we hope to maximize the number of children who will receive mobility-enhancing post-secondary education.

\section{Acknowledgements}

We thank Anne H. Gauthier, Ph.D., University of Calgary and Principal Investigator of the Canadian portion of the study, for helpful substantive and analytical comments. An early version of this paper benefited from the sage comments of Glen Elder Jr and Walter Heinz at the Conference of the Society for Longitudinal and Life Course Studies in Cambridge, UK, in September 2010, and we appreciate the helpful comments of the journal reviewers. We also thank the families who generously participated in this research.

\section{References}

Acs $G$ and Nichols A. (2010) America insecure: changes in the economic security of American families. LowIncome Working Families Paper \#16. Urban Institute, Washington, DC.

Birdsall N, Graham C and Pettinato S. (2000) Stuck in the tunnel: have new markets muddled the middle? Center on Social and Economic Dynamics Working Paper Series No. 14 (May). The Brookings Institution, Washington, DC.

Bourdieu P. (2001) The forms of capital. In M Granovetter and R Swedberg. eds. The sociology of economic life. Pp. 96-111. Westview, Boulder, CO.

Brand JE and Xie Y. (2010) Who benefits most from college? Evidence for negative selection in heterogeneous economic returns to higher education. American Sociological Review, 75, 273-302.

Chan S. (2011, January 5) Fed chief offers positive'11 view. The Philadelphia Inquirer, pp. A7, 9.

Coleman, JS. (1990) Foundations of social theory. Belknap, Cambridge, MA.

Conger RD, Conger KJ and Elder GH Jr. (1997) Family economic hardship and adolescent adjustment: mediating and moderating processes. In GJ Duncan and JJ Brooks-Gunn. eds. Consequences of growing up poor. Pp 288-339. Russell Sage Foundation, New York.

Cramer R, O'Brien R, Cooper D and Luengo-Prado M. (2009) A penny saved is mobility earned: advancing economic mobility through savings. Pew Charitable Trusts, Philadelphia, PA.

Danziger S and Ratner D. (2010) Labor market outcomes and the transition to adulthood. Future of Children, 20, 133-158.

Dynan K. (2010) The income roller-coaster: rising income volatility and its implications. First Focus Campaign for Children, Washington, DC.

Elder GH Jr. (1999) Children of the Great Depression: social change in life experience, $25^{\text {th }}$ Anniversary Edition. Westview, Boulder, CO.

Elliott W and Beverly S. (2010) The role of savings and wealth in reducing 'wilt' between expectations and college attendance. CSD Working Papers \#10-01. Washington University in St. Louis, Center for Social Development, St. Louis, MO. 
FinAid.org. (2010) Middle income. Retrieved August 20, 2010, from http://www.finaid.org/educators/middleincome.phtml

Furstenberg, FF. (2005) Banking on families: how families generate and distribute social capital. Journal of Marriage and Family, 67, 809-821.

Furstenberg FF Jr, Cook TD, Eccles J, Elder GH Jr and Sameroff A. (1999) Managing to make it: urban families and adolescent success. University of Chicago Press, Chicago.

Furstenberg FF and Gauthier AH. (2007) Families in the middle: a cross-national study of middle-income families in high-income economies. Proposal to the Russell Sage Foundation, March. (Contact:

fff@sas.upenn.edu to request copy)

Garcia J and Draut T. (2009) The plastic safety net: how households are coping in a fragile economy. Dēmos, New York.

Gauthier AH, Budd J, Furstenberg FF and Pacholok S. (2010) Families, financial strain, and the economic crisis. Paper presented at the European Population Conference, September 2010.

Goodman PS. (2010) The new poor: millions of unemployed face years without jobs. Retrieved March 15, 2010, from http://www.nytimes.com

Grusky DB. ed. (1994) Social stratification: class, race, and gender in sociological perspective. Westview, Boulder, CO.

Haley-Lock A and Shah MF. (2007) Protecting vulnerable workers: how public policy and private employers shape the contemporary low-wage work experience. Families in Society, 88, 485-495.

Hartmann H, English A and Hayes J. (2010) Women's and men's employment and unemployment in the Great Recession. Institute for Women's Policy Research, Washington, DC.

Haveman RH, Heinrich CJ and Smeeding TM. (2011) Jobs, skills, and policy for lower-wage workers. Fast Focus, 10, 1-6.

Holzer H. (2010) Fighting poverty and unemployment in an era of high debt. Spotlight on Opportunity, Washington, DC.

International Labour Organization. (2011) Global employment trends: the challenge of a jobs recovery. International Labour Office, Geneva.

Irons J. (2009) Economic scarring: the long-term impacts of the recession. Economic Policy Institute, Washington, DC.

Irwin N. (2011) Bernanke: economy can withstand recent setbacks. Retrieved June 8, 2011, from http://www.washingtonpost.com

Iversen RR and Armstrong AL. (2006) Jobs aren't enough: toward a new economic mobility for low-Income families. Temple University Press, Philadelphia.

Kneebone E and Garr E. (2010) The suburbanization of poverty: trends in metropolitan America, 2000 to 2008. Brookings, Washington, DC.

Lambert SJ and Henly JR. (2009) Scheduling in hourly jobs: promising practices for the twenty-first century economy. The Mobility Agenda, Washington, DC. http://www.mobilityagenda.org

Land KJ. (2010) Child and Youth Well-Being Index (CWI). Duke University, Durham, NC.

Lin N. (2001) Social capital: a theory of social structure and action. Cambridge University Press, Cambridge, UK.

Lino M. (2010) Expenditures on children by families, 2009. Miscellaneous Publication No. 1528-2009. U.S. Department of Agriculture, Center for Nutrition Policy and Promotion, Washington, DC.

Lovell P and Isaacs JB. (2010) Families of the recession: unemployed parents and their children. First Focus Campaign for Children, Washington, DC.

Mayer SE. (2010) Revisiting an old question: how much does parental income affect child outcomes? Focus, 27, 21-26.

McLoyd VC. (1998) Socioeconomic disadvantage and child development. American Psychologist, 53, 185-204.

McNichol E, Oliff P and Johnson N. (2011) States continue to feel recession's impact. Center on Budget and Policy Priorities, Washington, DC.

Metropolitan Philadelphia Indicators Project (MPIP). (2010) Where we stand: community indicators for metropolitan Philadelphia. William Penn Foundation and Temple University, Philadelphia, PA.

Mistry RS, Vandewater EA, Huston AC and McLoyd VC. (2002) Economic well-being and children's social adjustment: the role of family process in an ethnically diverse low-income sample. Child Development, 73, 935-951.

O'Leary K. (2010) The Great Recession: will construction workers survive? Retrieved June 11, 2011, from www.time.com

Oreopoulos P, Page M and Stevens AH. (2008) The intergenerational effects of worker displacement. Journal of Labor Economics, 26, 455-483. 
Parcel TL, Dufur MJ and Zito RC. (2010) Capital at home and at school: a review and synthesis. Journal of Marriage and Family, 72, 828-846.

Pressman S. (2007) The decline of the middle class: an international perspective. Journal of Economic Issues, 41, 181-200.

Pressman, S and Scott RH III. (2010) Consumer debt and poverty measurement. Focus, 27, 9-12.

Skocpol T. (2001) The missing middle: working families and the future of American social policy. W.W. Norton, New York.

Stein R. (2010) Low-quality child care can have lasting impact. The Washington Post, May 14. Retrieved May 14, 2010 from http://www.msnbc.msn.com

Strohschein L. (2005) Household income histories and child mental health trajectories. Journal of Health and Social Behavior, 46, 359-375.

Tufano P and Schneider D. (2010) Supporting saving by low- and moderate-income families. Focus, 27, 19-25.

U.S. Department of Labor. (2010) A profile of the working poor, 2008. Report 1022. U.S. Department of Labor, U.S. Bureau of Labor Statistics, Washington, DC.

Von Wachter T. (2011) Challenges for the U.S. economic recovery. Washington, DC: Testimony before the Budget Committee. Retrieved June 11, 2011, from http://www.columbia.edu.

Voydanoff P. (1990) Economic distress and family relations: A review of the eighties. Journal of Marriage and Family, 52, 1099-1115.

Weber M. (1978) Economy and society, Volume 2. In G Roth and C Wittich. eds. University of California Press, Berkeley, CA. (Original work published 1922).

Williams JC and Boushey H. (2010) The three faces of work-family conflict: the poor, the professionals, and the missing middle. Center for American Progress, Washington, DC.

Yeung WJ, Linver MR and Brooks-Gunn J. (2002) How money matters for young children's development: parental investment and family processes. Child Development, 73, 1861-1879.

\section{Endnotes}

'The U.S.-based research was generously funded by the Russell Sage Foundation to Frank F Furstenberg. '”

ii We were unable to locate five families and did not re-contact the sixth family whose contact parent had been extremely ill at the 2008 interview.

iii Other than income, which was a selection criterion in both years, the 2008 and 2009 interview samples are substantively very similar and both samples are similar to the 238 respondents to the 2008 short survey.

iv Twenty-five families were interviewed in both 2008 and 2009, yielding prospective as well as retrospective data. Five additional families were interviewed in 2009 only, but had provided responses to the 2008 survey and retrospective commentary on their lives since then in the 2009 interview.

${ }^{\vee}$ All names are pseudonyms

${ }^{v i}$ COBRA (Consolidated Omnibus Budget Reconciliation Act of 1986 health benefit provisions) is a federal policy that "provides certain employees, retirees, spouses....the right to temporary continuation of health coverage at group rates" (Retrieved June 17, 2011, from http://dol.gov/ebsa/pdf/faq-consumer-cobra.pdf

vii Thanks to Daniel Meyer, University of Wisconsin-Madison, Institute for Research on Poverty, for urging us to also mention the positive aspect of refinancing.

viii The exception to this statement is that most parents of the children diagnosed as special needs expect that a high school diploma will probably be the highest level of education their children can reach. 